\title{
Changes in abundance of coral-reef bottom components related to mass mortality of the sea urchin Diadema antillarum
}

\author{
E. D. de Ruyter van Steveninck ${ }^{1} \&$ R. P. M. Bak ${ }^{2}$ \\ ${ }^{1}$ Biological Centre, Dept. of Marine Biology, PO Box 14, NL-9750 AA Haren (Gn), The Netherlands \\ ${ }^{2}$ Netherlands Institute for Sea Research (N.I.O.Z.), PO Box 59, NL-1790 AB Den Burg, Texel, The Netherlands
}

\begin{abstract}
We studied the effect of a reduction in grazing pressure, following mass mortalities of the abundant sea urchin Diadema antillarum, on coral-reef bottom components at Curaçao (Netherlands Antilles). We surveyed cover of fleshy and filamentous algae, scleractinian corals, crustose coralline algae, loose sediment and a miscellaneous category in permanent quadrats at depths of 27,15 and $3 \mathrm{~m}$ during 1 yr. At all depths, cover of fleshy and filamentous algae increased significantly, reaching a new equilibrium. Corals, crustose corallines and/or loose sediment generally decreased in cover, but not all changes were significant. At the species level, we found the coral Agaricia agaricites, at $15 \mathrm{~m}$, to be relatively vulnerable among corals. The macroalgae Lobophora variegata and Dictyota spp. increased significantly in cover at 27 and $15 \mathrm{~m}$, respectively. We expect, in view of the observed continuously low rates of recruitment of $D$. antillarum, and in view of the new equilibrium in algal cover, no rapid return to the original situation, unless other herbivorous organisms will take over the role of $D$. antillarum.
\end{abstract}

\section{INTRODUCTION}

Grazing of fleshy and filamentous algae by marine herbivores is an important factor in the dynamic balance between benthic organisms, because algae are efficient competitors for space. When common grazers increase in numbers or are annihilated, dramatic changes may occur in the abundance of dominant organisms. Recent examples include the welldocumented impact of sea urchins on populations of macroalgae (Breen \& Mann 1976, Pearse \& Hines 1979 , Chapman 1981, Miller 1985).

Similar mechanisms are operative in coral-reef communities. Grazing organisms are found among molluscs and small crustaceans (Brawley \& Adey 1981) but fishes and sea urchins are the main groups of herbivores, though their relative importance varies with characteristics of the reef habitat (Randall 1965, Ogden et al. 1973, Ogden \& Lobel 1978, Hay 1984). Competition for space on the limited hard substratum occurs between an array of organisms and is a possible structuring force on many reefs (Jackson \& Buss 1975, Jackson 1977, Karlson 1980, Benayahu \& Loya 1981, Bak et al. 1982, Bak \& Borsboom 1984). Although algae are often not very obtrusive in the reef environment, small algae are very common and, as demonstrated for example in the territories of damselfishes, they become very dominant when there is a reduction in grazing pressure (Ogden \& Lobel 1978, Borowitzka 1981. Gaines \& Lubchenco 1982).

Much evidence for the impact of grazers on coral reefs has been collected in experiments with the sea urchin Diadema antillarum Philippi, and variation of grazing pressure of $D$. antillarum appeared to influence competition of bottom components (Wanders 1977), survival of coral recruits (Sammarco 1980) and algal community structure (Carpenter 1981, Sammarco $1982 b)$. Cages were usually employed to control the densities of $D$. antillarum in inclusion/exclusion experiments. Experiments free of possible cage effects were executed on isolated patch reefs (Sammarco et al. 1974, Sammarco 1982a), but were not feasible in most reef situations (but see Hay \& Taylor 1985). However, a great natural experiment was initiated when, in the course of 1983, mass mortalities of $D$. antillarum swept the Caribbean (Lessios et al. 1983, 1984a, b, Bak et al. 1984, Hughes et al. 1985). These mortalities, thought to be caused by a water-borne pathogen, hit the reefs of 
Curaçao (Netherlands Antilles) in October 1983, and, within weeks, reduced populations of $D$. antillarum to a few percent or less of their former values (Bak et al. 1984)

Pre-mortality recruitment rates of Diadema antillarum varied significantly on different sites along the coast of Curaçao (Bak 1985), but persistently low postmortality recruitment (Bak 1985, de Ruyter van Steveninck pers. obs.) indicates that an important long-term effect may be expected.

Extrapolating from experimental data in the literature (Earle 1972, Wanders 1977, Ogden \& Lobel 1978, Williams 1981, Sammarco 1982a, b) and the extensive data available on these particular reef sites (van den Hoek et al. 1975, 1978, Wanders 1977, Bak \& Engel 1979, Bak \& Luckhurst 1980, de Ruyter van Steveninck \& Breeman 1981, van Duyl 1985), we predicted the following obvious changes in bottom components to occur: increase in cover of fleshy and filamentous algae, decrease in cover of scleractinian corals, particularly noticeable in a species such as Agaricia agaricites (Linnaeus), decrease in cover of crustose coralline algae, and possibly decreases in sandy sediment and miscellaneous organisms. To record such changes, we studied permanent quadrats at 27,15 and $3 \mathrm{~m}$ depth for a period of $1 \mathrm{yr}$ following the outbreak of the Diadema antillarum mortality.

Although of necessity the customary control experiment is lacking, comparisons with events at other Caribbean sites (Carpenter 1985, Hughes et al. 1985, Liddell \& Ohlhorst 1986), where Diadema antillarum mortalities occurred at a different time, will provide the spatial and temporal replication required to ascribe the observed changes to the dramatic reduction in $D$. antillarum densities.

\section{MATERIAL AND METHODS}

Our observations were made at CARMABI Buoy 1, a well-studied reef on the south-west, leeward coast of Curaçao. For a general description of the area see van den Hoek et al. (1975). Detailed descriptions of the coral-reef bottom components can be found in Bak (1977) and van den Hoek et al. $(1975,1978)$. At Buoy 1, mortalities in the Diadema antillarum population started on 8 October 1983, and more than $50 \%$ of the population was dying by 12 October.

We established 5 permanent $1 \mathrm{~m}^{2}$ quadrats at each of 3 depths: $27 \mathrm{~m}$ (14 to $18 \mathrm{Oct}$ ), $15 \mathrm{~m}$ (10 to $12 \mathrm{Oct}$ ) and $3 \mathrm{~m}$ (12 to $14 \mathrm{Oct}$ ). At opposite corners of a quadrat, 2 stakes were driven into the reef bottom. At each survey (see abscissa in Fig. 1 for time intervals), a frame, spanned with nylon string in 10 regular rows and columns, was laid over a quadrat. The nylon string provided 100 point intercepts and at each point a small brass chain was used as a perpendicular line to obtain 100 sampling points on the reef bottom. The bottom component at the point of contact was recorded.

We distinguished the following components: fleshy and filamentous algae, crustose coralline algae (Corallinaceae), corals (Scleractinia), loose sediment and miscellaneous. Close inspection of 'bare' rock almost invariably revealed the presence of filamentous algae. Really bare rock never exceeded $3 \%$ of cover, and this small category was grouped with miscellaneous. Macroalgae, corals and miscellaneous organisms were actually identified to the species (or genus) level (see 'Appendix'), but the data are not sufficient to detect significant changes at this level. Exceptions could be made for the algae Lobophora variegata (Lamouroux) Womersley at $27 \mathrm{~m}$ and Dictyota spp. at 27 and $15 \mathrm{~m}$, and for the coral Agaricia agaricites at $15 \mathrm{~m}$.

Cover data in the permanent quadrats were recorded as percentages. The disappearance of quadrats at $15 \mathrm{~m}$ is responsible for the loss of our last series of data points at this depth. To compare original and final cover statistically, using t-tests for paired comparisons (1-tailed), we transformed the cover data with angular transformation (Sokal \& Rohif 1981).

\section{RESULTS}

Changes in bottom cover for each component and each survey during the year are shown in Fig. 1. Relative changes in cover since the Diadema antillarum mass mortalities (if significant, $p<0.05$ ) are listed in Table 1. Profound changes in the composition of bottom components have occurred since the onset of our survey. Most pronounced is the significant increase in cover of fleshy and filamentous algae at all 3 depths ( $p<0.01, p<0.05, p<0.025 ; 27,15,3 \mathrm{~m}$, respectively). This increase paralleled decreases in cover of crustose coralline algae $(p<0.001, p<0.05 ; 27,3 m$, respectively) and sediment $(p<0.01, p<0.025 ; 15,3 \mathrm{~m}$, respectively). However, the decrease in coral cover at $27 \mathrm{~m}(16 \%)$ is not significant $(0.05<\mathrm{p}<0.10)$ and the remainder of living bottom components, grouped in the miscellaneous category, is apparently too heterogeneous to react in a particular direction.

It appears that, in the only case where we could observe a change in corals at the species level, Agaricia agaricites showed a response that differed from the remainder of the scleractinians at that depth $(15 \mathrm{~m})$. Where mean cover of the remaining group of corals does not change $(\mathrm{p}>0.10), A$. agaricites shows a significant decrease $(p<0.05)$.

Our data on the larger macroalgae indicate a signifi- 

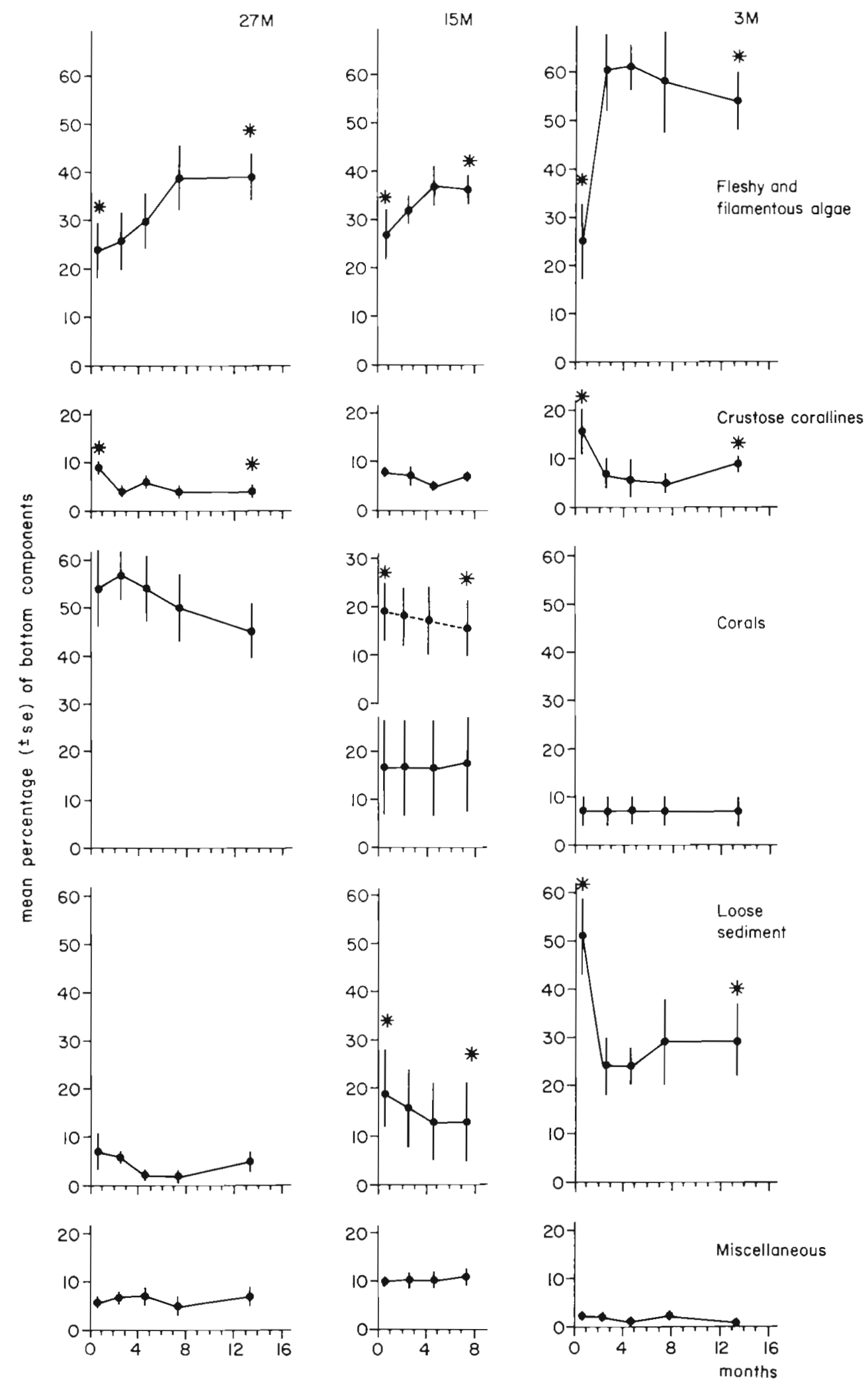

Fig. 1. Mean percentage cover $( \pm \mathrm{SE})$ of bottom components in permanent quadrats $\left(1 \mathrm{~m}^{2}, \mathrm{n}=5\right)$ at 3 depths between Oct 1983 and Nov $1984(27,3 \mathrm{~m})$ and between Oct 1983 and May $1984(15 \mathrm{~m})$, respectively. Asterisks: significant change over time (t-test for paired comparisons, 1 -tailed, $\mathrm{p}<0.05$ ). For corals at $15 \mathrm{~m}$ : broken line, Agaricia agaricites only; solid line, remainder of coral 
Table 1. Significant changes $(p<0.05)$ in cover at last survey as a percentage of initial cover (in October 1983) in permanent quadrats at 3 depths on the reef

\begin{tabular}{|lccc|}
\hline Bottom component & $\begin{array}{c}27 \mathrm{~m} \\
\text { (Nov 84) }\end{array}$ & $\begin{array}{c}15 \mathrm{~m} \\
\text { (May 84) }\end{array}$ & $\begin{array}{c}3 \mathrm{~m} \\
\text { (Nov 84) }\end{array}$ \\
\hline $\begin{array}{l}\text { Fleshy and filamentous } \\
\text { algae }\end{array}$ & +60 & +32 & +118 \\
$\begin{array}{l}\text { Lobophora variegata } \\
\text { Dictyota spp. }\end{array}$ & +900 & & \\
$\begin{array}{l}\text { Crustose corallines } \\
\text { Agaricia agaricites } \\
\text { Loose sediment }\end{array}$ & -57 & $+\infty$ & -40 \\
\hline
\end{tabular}

cant increase of Lobophora variegata in the permanent quadrats $(27 \mathrm{~m}, 0.2$ to $2.0 \%, p<0.025)$. Dictyota spp. increased at $15 \mathrm{~m}(0$ to $2.0 \%, \mathrm{p}<0.025)$. At $27 \mathrm{~m}$, there was a significant initial expansion (4.4 to $16.8 \%$, $\mathrm{p}<0.025$ ), but at the end of the year the abundance of Dictyota spp. was again at the original level.

\section{DISCUSSION}

The virtual disappearance of Diadema antillarum had obvious effects on the composition of the reef bottom which are, to a large degree, in accordance with our predictions. There was an immediate increase in algal cover which reached a plateau in 2 to 7 mo, dependent upon depth, suggesting a new equilibrium in algal biomass and predation. Herbivorous fishes are the main group of grazers in the new situation, and the change in cover indicates that competition for food occurred between fishes and urchins in pre-mortality conditions. This is supported by observations that, after experimental removal of $D$. antillarum, the number of herbivorous fishes as well as their activity increased (Ogden et al. 1973, Hay \& Taylor 1985). Morrison (1984) and Carpenter (1985) also reported an increase of grazing activities by herbivorous fishes in shallow reefs following $D$. antillarum mortalities at Jamaica and St. Croix, respectively.

The present study does not have a true control and is only replicated within the permanent quadrats at the 3 depths. Both spatial and temporal replication is obtained when we compare all data available from the Caribbean on changes in algal cover or biomass following Diadema antillarum mortality. The observed changes, 7 to 13 mo following $D$. antillarum mortality, are summarised in Table 2 : at all locations and depths, except Jamaica, $22 \mathrm{~m}$, significant increase in algal cover or biomass was observed. Fisher's test for combining probabilities from independent tests of significance (Sokal \& Rohlf 1981) showed significant increase in algal cover or biomass for each of the 3 depth categories ( 2 to $7 \mathrm{~m} ; 15 \mathrm{~m} ; 22$ to $27 \mathrm{~m}$ : Table 2 ). Because this method provides both spatial and temporal replication, the increase in algal cover or bio-

Table 2. Summary of changes in algal cover (Curaçao, Jamaica) or biomass (St. Croix), following Diadema antillarum mass mortalities, at various locations. Included are test-result probabilities required to carry out Fisher's method of combining probabilities from independent tests of significance (Sokal \& Rohlf 1981), $t=0$ : start of observations, $t=x$ : termination of observations

\begin{tabular}{|c|c|c|c|c|c|c|}
\hline Location & $\begin{array}{l}\text { Depth } \\
\text { (m) }\end{array}$ & $\begin{array}{l}\text { Date of first } \\
\text { mortality }\end{array}$ & Observational period & $\begin{array}{c}\text { Cover/biomass (SD) } \\
t=0 \quad t=x\end{array}$ & $\begin{array}{l}\text { Probability } \\
\text { value }\end{array}$ & $\begin{array}{l}\text { Statistical test } \\
\text { and source }\end{array}$ \\
\hline Curaçao & $\begin{array}{r}3 \\
15 \\
27\end{array}$ & $\begin{array}{l}8 \text { Oct } 1983 \\
8 \text { Oct } 1983 \\
8 \text { Oct } 1983\end{array}$ & $\begin{array}{l}\text { 12/14 Oct } 1983-\text { Nov } 1984 \\
10 / 12 \text { Oct } 1983-\text { Nov } 1984 \\
14 / 18 \text { Oct } 1983-\text { Nov } 1984\end{array}$ & $\begin{array}{l}25.0(17.9)-54.4(16.0) \% \\
27.4(11.4)-36.2(6.8) \% \\
24.2(13.6)-38.8(12.2) \%\end{array}$ & $\begin{array}{l}0.012 \\
0.036 \\
0.0065\end{array}$ & $\begin{array}{l}\text { t-tests for paired com- } \\
\text { parisons; this study }\end{array}$ \\
\hline St. Croix & $1.5-2$ & 5 Feb 1984 & 15 Feb 1984-Dec 1984 & $\begin{array}{c}3.8(1.7)-13.2(12.2) \\
\mathrm{mg} \mathrm{cm}^{-2}\end{array}$ & $<0.001$ & $\begin{array}{l}\text { t'-test for heterogene- } \\
\text { ous variances (Sokal } \\
\& \text { Rohlf 1981) carried } \\
\text { out on data from Car- } \\
\text { penter (1985): Fig. } 1\end{array}$ \\
\hline $\begin{array}{l}\text { Jamaica } \\
\text { (Rio Bueno) }\end{array}$ & 7 & 26 Jul 1983 & 22 Jul 1983-Jun 1984 & $3-15$ & $<0.001$ & $\begin{array}{l}\text { Mann-Whitney U test; } \\
\text { Hughes et al. (1985) }\end{array}$ \\
\hline $\begin{array}{l}\text { Jamaica } \\
\text { (West Fore }\end{array}$ & 5 & $\begin{array}{l}\text { Early Aug } \\
1983\end{array}$ & End Aug 1983-Aug 1983 & $55.4(6.6)-72.7(10.0) \%$ & $<0.001$ & $\begin{array}{l}\text { Chi-square test of in- } \\
\text { dependence carned }\end{array}$ \\
\hline Reef) & $\begin{array}{l}15 \\
22\end{array}$ & $\begin{array}{l}\text { Early Aug } \\
1983 \\
\text { Early Aug } \\
1983\end{array}$ & $\begin{array}{l}\text { End Aug 1983-Aug } 1983 \\
\text { End Aug 1983-Aug } 1983\end{array}$ & $\begin{array}{l}49.7(5.9)-64.7(7.5) \% \\
56.1(14.9)-57.4(4.9) \%\end{array}$ & $\begin{array}{l}<0.001 \\
0.75<\mathrm{p} \\
<0.90\end{array}$ & $\begin{array}{l}\text { out on data from } \\
\text { Liddell \& Ohlhorst } \\
\text { (1986): Table } 1\end{array}$ \\
\hline
\end{tabular}


Table 3. Time intervals involved in the increase and subsequent levelling of algal cover or biomass following Diadema antillarum mass mortalities. The new equilibrium levels are presented as percentage increase relative to cover or biomass at the start of observations

\begin{tabular}{|lccccc|}
\hline Location & Depth $(\mathrm{m})$ & $\begin{array}{c}\text { Period of increase } \\
(\mathrm{mol}\end{array}$ & $\begin{array}{c}\text { New level persisted } \\
\text { for at least (mo) }\end{array}$ & $\%$ increase & Source \\
\hline Curaçao & 3 & $0-2$ & 11 & $118-146$ & This study \\
& 15 & $0-4$ & 3 & $32-35$ & This study \\
St. Croix & 27 & $0-7$ & 3 & 60 & This study \\
Jamaica & $1.5-2$ & $0-7$ & 8 & 245 & Carpenter (1985) \\
& 7 & $0-3$ & Hughes et al. (1985) \\
\hline
\end{tabular}

mass must undoubtedly be effected by the $D$. antillarum mass mortalities. In addition, there is in none of these cases any indication that other factors, such as seasonality, have been involved. Although basically the same phenomenon occurred at all sites, i.e. increase of algal cover or biomass until a new level was reached, there was some variation in the time to reach this new level ( 2 to $7 \mathrm{mo}$ ) and in the relative increase (32 to $400 \%$; Table 3). Probably, differences in initial cover of algae and other substratum components and in the abundance of herbivores are responsible. However, it appears that these newly established equilibrium levels persisted at all sites (Table 3 ) until termination of the observations ( 3 to $11 \mathrm{mo}$ ).

In view of pre-mortality densities of Diadema antillarum, the most pronounced effects on algal abundance in Curaçao could be expected at 3 and $15 \mathrm{~m}: 2.9$ and 2.5 urchins $\mathrm{m}^{-2}$, respectively (Bak et al. 1984), compared with only $0.4 \mathrm{D}$. antillarum $\mathrm{m}^{-2}$ at $27 \mathrm{~m}$ (de Ruyter van Steveninck unpubl.). If an increase in algal abundance may be interpreted as a simple function of algal growth rates and herbivory, fish grazing pressure seems to be most manifest at $15 \mathrm{~m}$, as indicated by the smallest increase in algal cover at that depth.

Algae are known to limit settlement and survival of crustose corallines (Vine 1974, Wanders 1977) and corals (Potts 1977, Bak \& Engel 1979, Sammarco 1980, 1982a, Fitz et al. 1983, Rosesmyth 1984, van Moorsel 1985), and are very common competitors for space at the periphery of scleractinian corals (Liddell et al. 1984, Bak unpubl.). This finds expression in the significant decrease of crustose coralline algae at 27 and $3 \mathrm{~m}$. However, corals were only slightly reduced in cover at $27 \mathrm{~m}$, indicating their ability to compete effectively with algae (de Ruyter van Steveninck unpubl.). One exception is Agaricia agaricites which appeared to be more susceptible to increased competition with denser algal turfs than the average coral at $15 \mathrm{~m}$. This confirms our view of $A$, agaricites as a relatively vulnerable coral (Bak 1983), suffering high mortalities that result in a very mobile spatial distribution pattern (Bak \& Luckhurst 1980, Hughes \& Jackson 1985). At 3 and
$15 \mathrm{~m}$ a significant part of the algal increase occurred over loose sandy sediments. The importance of differences in algal species composition for these differences in extension patterns of the algal turfs at the 3 depths is unknown. In Jamaica (West Fore Reef) the increase in algal cover was mainly achieved at the expense of crustose corallines and clionid sponges (Liddell \& Ohlhorst 1986) and, at Rio Bueno, most of the algal growth had taken place over previously bare substratum (Hughes et al. 1985), thus confirming the findings of the present study.

With the reduction in grazing pressure, changes in the species composition of the reef vegetations can be expected (Sammarco et al. 1974, Carpenter 1981, 1985). This effect is demonstrated by the significant increase in cover of Dictyota spp. and Lobophora variegata. Grazing experiments with $L$. variegata in Curaçao showed that fish continued to graze on $L$. variegata, but that total grazing pressure on this species was lower than before Diadema antillarum mortality (de Ruyter van Steveninck unpubl.). This explains the increase in cover of this alga during our observation period. A similar increase was reported from Jamaica (Morrison 1984, Liddell \& Ohlhorst 1986). Why Dictyota spp. densities at one depth $(27 \mathrm{~m})$ were reduced to the original levels is unclear. There are indications that these algae form a rather dynamic component of the reef slope community (de Ruyter van Steveninck pers. obs.), and such sudden local changes in density may be a normal phenomenon in this species. The observed cover fluctuations of Dictyota spp. at Jamaica (Liddell \& Ohlhorst 1986) raise the same suggestion.

Recruitment of Diadema antillarum, though highly varying in space and time, used to follow a predictable pattern in Curaçao (Bak 1985). However, this pattern is totally disrupted and there has been virtually no settlement of $D$. antillarum on the reefs since March 1984 (Bak 1985, de Ruyter van Steveninck pers. obs. until December 1985). In view of this and of the observed equilibrium in algal cover, which, after an initial increase following $D$. antillarum mortality, was also 
Appendix. Species or genera identified within the categories 'fleshy and filamentous algae', 'scleractinian corals' and 'miscellaneous'. Mean percentage cover (SD) at first and last survey, respectively

\begin{tabular}{|c|c|c|c|c|c|c|}
\hline & \multicolumn{2}{|c|}{$27 \mathrm{~m}$} & \multicolumn{2}{|c|}{$15 \mathrm{~m}$} & \multicolumn{2}{|c|}{$3 \mathrm{~m}$} \\
\hline & Oct 1983 & Nov 1984 & Oct 1983 & May 1984 & Oct 1983 & Nov 1984 \\
\hline \multicolumn{7}{|l|}{ Fleshy and filamentous algae } \\
\hline Labophora variegata (Lamour.) Womersley & $0.2(0.5)$ & $2.0(2.0)$ & & & & \\
\hline Dictyota sp. & $4.4(5.9)$ & $5.0(3.7)$ & 0.0 & $2.0(1.4)$ & & \\
\hline Halimeda sp. & 0.0 & $1.2(2.7)$ & 0.0 & $0.4(0.6)$ & & \\
\hline Valonia sp. & & & 0.0 & $0.4(0.6)$ & & \\
\hline Wrangelia sp. & & & & & 0.0 & $0.2(0.5)$ \\
\hline Unidentified algal turf & $19.4(11.0)$ & $30.6(14.2)$ & $27.4(11.4)$ & $33.4(7.4)$ & $25.0(17.9)$ & $54.2(15.7)$ \\
\hline \multicolumn{7}{|l|}{ Scleractinian corals } \\
\hline Agaricia grahamae Wells & $13.2(12.5)$ & $13.6(11.3)$ & & & & \\
\hline \multicolumn{7}{|l|}{ A. lamarcki Milne Edwards \& Haime and } \\
\hline Colpophyllia natans (Müller) & $4.6(10.3)$ & $5.8(13.0)$ & & & & \\
\hline Dichocoenia stellaris Milne Edwards \& Haime & $0.8(1.8)$ & $0.8(1.8)$ & & & & \\
\hline Eusmilia fastigiata (Pallas) & $1.6(2.1)$ & $1.6(2.1)$ & & & & \\
\hline Mycetophyllia aliciae Wells & $0.2(0.5)$ & 0.0 & & & & \\
\hline Siderastrea siderea (Ellis et Solander) & $0.4(0.9)$ & $0.6(1.3)$ & & & & \\
\hline Agaricia agaricites (Linnaeus) & $11.8(13.9)$ & $9.0(8.5)$ & $19.8(8.0)$ & $15.0(7.1)$ & & \\
\hline Madracis decactis (Lyman) & $0.8(0.8)$ & $0.4(0.9)$ & $1.8(1.9)$ & $1.4(1.1)$ & & \\
\hline Meandrina meandrites (Linnaeus) & $7.8(9.1)$ & $4.2(6.9)$ & $1.0(0.7)$ & $1.2(1.6)$ & & \\
\hline Montastrea cavernosa (Linnaeus) & $0.6(0.9)$ & $0.6(0.9)$ & $3.2(4.7)$ & $2.6(4.8)$ & & \\
\hline $\begin{array}{l}\text { Stephanocoenia michelinii Milne Edwards } \\
\text { \& Haime }\end{array}$ & $10.8(11.6)$ & $7.6(7.6)$ & $1.8(3.5)$ & $2.4(5.4)$ & & \\
\hline Porites astreoides Lamarck & $1.0(1.0)$ & $0.8(0.8)$ & $0.6(0.6)$ & $0.6(1.3)$ & $1.6(2.3)$ & $0.6(0.9)$ \\
\hline Leptoseris cucullata (Elis et Solander) & & & $0.2(0.5)$ & 0.0 & & \\
\hline Madracis mirabilis (Duchassaing et Michelotti) & & & $4.6(8.7)$ & $4.0(8.9)$ & & \\
\hline Montastrea annularis (Ellis et Solander) & & & $2.6(2.5)$ & $4.2(5.4)$ & $3.4(7.1)$ & $3.8(6.9)$ \\
\hline Porites porites (Pallas) & & & $0.4(0.9)$ & $0.8(1.3)$ & 0.0 & $0.2(0.5)$ \\
\hline Acropora palmata (Lamarck) & & & & & $0.4(0.9)$ & $0.8(1.8)$ \\
\hline Agaricia humilis Verrill & & & & & $0.2(0.5)$ & $0.4(0.6)$ \\
\hline Diploria labyrinthiformis (Linnaeus) & & & & & $0.4(0.9)$ & $0.6(0.9)$ \\
\hline D. strigosa (Dana) & & & & & $0.4(0.9)$ & $0.4(0.9)$ \\
\hline Siderastrea radians (Pallas) & & & & & $0.2(0.5)$ & $0.2(0.3)$ \\
\hline \multicolumn{7}{|l|}{ Miscellaneous } \\
\hline Millepora sp. & & & $1.0(0.7)$ & $1.4(1.1)$ & $0.8(1.1)$ & 0.0 \\
\hline Erythropodium of. polyanthes & $1.0(1.2)$ & $1.2(1.3)$ & & & & \\
\hline Nucella sp. & & & $2.0(3.1)$ & $1.0(1.2)$ & & \\
\hline Condylactis gigantea (Weinland) & & & & & $0.2(0.5)$ & $0.2(0.5)$ \\
\hline Lebrunia danae (Duchassaing et Michelotti) & $0.2(0.5)$ & 0.0 & 0.0 & $0.2(0.5)$ & $0.2(0.5)$ & 0.0 \\
\hline Unidentified anemone & & & $0.2(0.5)$ & $0.4(0.6)$ & & \\
\hline Agelas conifera (Schmidt) & & & $0.4(0.9)$ & $0.4(0.9)$ & & \\
\hline A. sceptrum (Lamarck) & & & $0.6(1.3)$ & $0.2(0.5)$ & & \\
\hline Ircinia campana (Lamarck) & & & $0.8(1.8)$ & $1.0(2.2)$ & & \\
\hline $\begin{array}{l}\text { Neofibularia nolitangere (Duchassaing } \\
\text { et Michelotti) }\end{array}$ & & & $0.6(0.9)$ & $0.6(1.3)$ & & \\
\hline Unidentified sponge & & & & & $0.2(0.5)$ & 0.0 \\
\hline Unidentified boring sponge ( $\beta$ phase) & $2.0(2.4)$ & $2.6(2.4)$ & $2.2(2.8)$ & $1.4(0.9)$ & $0.2(0.5)$ & 0.0 \\
\hline Trididemnum solidum (Van Name) & $0.2(0.5)$ & 0.0 & $0.4(0.9)$ & $1.0(1.7)$ & & \\
\hline Gypsina sp. & $1.2(1.3)$ & $1.0(1.2)$ & 0.0 & $0.2(0.5)$ & & \\
\hline Unidentified & $0.6(0.9)$ & $1.8(1.1)$ & 0.0 & $1.4(1.5)$ & & \\
\hline Bare substrate & $0.6(0.6)$ & $0.4(0.6)$ & $1.8(0.8)$ & $2.0(2.4)$ & 0.0 & $0.2(0.5)$ \\
\hline
\end{tabular}

observed in Lobophora variegata vegetations (de Ruyter van Steveninck unpubl.), and was repeatedly observed at various other locations (Carpenter 1985 , Hughes et al. 1985), we foresee no rapid return to the former level and mode of herbivory, unless grazing pressure by other herbivorous organisms will increase to compensate for the virtual disappearance of $D$. antillarum on the coral reefs of Curaçao.

Acknowledgements. Working facilities were provided by the Caribbean Marine Biological Institute. We thank O. Frans, F. Isabella and $\mathrm{A}$. Tiel for assistance in the field; and $\mathrm{C}$. van den 
Hoek, A. M. Breeman and L. L. van Mulekom for critically reading the manuscript. The manuscript has benefitted from the comments of one anonymous referee. The first author was supported by grant W84-201 from the Netherlands Foundation for the Advancement of Tropical Research (WOTRO).

\section{LITERATURE CITED}

Bak, R. P. M. (1977). Coral reefs and their zonation in the Netherlands Antilles. Am. Ass. Petrol. Geol. USA Stud. Geol. 4: 3-16

Bak, R. P. M. (1983). Neoplasia, regeneration and growth in the reef-building coral Acropora palmata. Mar. Biol. 77: $221-227$

Bak, R. P. M. (1985). Recruitment patterns and mass mortalities in the sea urchin Diadema antillarum. Proc. Fifth Int. Coral Reef Congr. Tahiti 5: 267-272

Bak, R. P. M., Borsboom, J. L. A. (1984). Allelopathic interaction between a reef coelenterate and benthic algae. Oecologia (Berl.) 63: 194-198

Bak, R. P. M., Carpay, M. J. E., de Ruyter van Steveninck, E. D. (1984). Densities of the sea urchin Diadema antillarum before and after mass mortalities on the coral reefs of Curaçao. Mar. Ecol. Prog. Ser. 17: 105-108

Bak, R. P. M., Engel, M. S. (1979). Distribution, abundance and survival of juvenile hermatypic corals (Scleractinia) and the importance of life history strategies in the parent coral community. Mar. Biol. 54: 341-352

Bak, R. P. M., Luckhurst, B. E. (1980). Constancy and change in coral reef habitats along depth gradients at Curaçao. Oecologia (Berl.) 47: 145-155

Bak, R. P. M., Termaat, R. M., Dekker, R. (1982). Complexity of coral interactions: influence of time, location of interaction and epifauna. Mar Biol. 69: 215-222

Benayahu, Y., Loya, Y (1981). Competition for space among coral-reef sessile organisms at Eilat, Red Sea. Bull. mar Sci. 31: 514-522

Borowitzka, M. A. (1981). Algae and grazing in coral reef ecosystems. Endeavour (New Ser.) 5: 99-106

Brawley, S. H., Adey, W. H. (1981). The effect of micrograzers on algal community structure in a coral reef microcosm. Mar. Biol. 61: 167-177

Breen, P. A., Mann, K. H. (1976). Destructive grazing of kelp by sea urchins in eastern Canada. J. Fish. Res. Bd Can. 33 $1278-1283$

Carpenter, R. C. (1981). Grazing by Diadema antillarum Philippi and its effects on the benthic algal community. $\mathrm{J}$. mar. Res. 39: 749-765

Carpenter, R. C. (1985). Sea urchin mass-mortalities: effects on reef algal abundance, species composition, and metabolism and other coral reef herbivores. Proc. Fifth Coral Reef Congr. Tahiti Vol. 4: 53-60

Chapman, A. R. O. (1981). Stability of sea urchin dominated barren grounds following destructive grazing of kelp in St. Margaret's Bay, Eastern Canada. Mar. Biol. 62: 307-311

Earle, S. A. (1972). The effects of herbivores on marine plants of Great Lameshur Bay, with an annotated list of plants. Results of the Tektite program: ecology of reef fishes. Nat. Hist. Mus. Los Angeles Co., Sci. Bull. 14: 17-44

Duyl, F. C. van (1985). Atlas of the living reefs of Curaçao and Bonaire (Netherlands Antilles). Foundation for Scientific Research in Surinam and the Netherlands Antilles Vol. 117, Utrecht

Fitz, H. C., Reaka, M. L., Bermingham, E., Wolf, N. G. (1983). Coral recruitment at moderate depths: the influence of grazing. Symp. Gen. Undersea Res. NOAA 1: 89-96
Gaines, S. D., Lubchenco, J. (1982). A unified approach to marine plant-herbivore interactions. II. Biogeography. Ann. Rev. Ecol. Syst. 13: 111-138

Hay, M. E. (1984). Patterns of fish and urchin grazing on Caribbean coral reefs: are previous results typical? Ecology $64: 446-454$

Hay, M. E., Taylor, P. R. (1985). Competition between herbivorous fishes and urchins on Caribbean reefs. Oecologia (Berl.) 65: 591-598

Hoek, C. van den, Breeman, A. M., Bak, R. P. M., van Buurt, G. (1978). The distribution of algae, corals and gorgonians in relation to depth, light attenuation, water movement and grazing pressure in the fringing reef of Curaçao, Netherlands Antilles. Aquat. Bot. 5: 1-46

Hoek, C. van den, Cortel-Breeman, A. M., Wanders, J. B. W. (1975). Algal zonation in the fringing coral reef of Curaçao, Netherlands Antilles, in relation to zonation of corals and gorgonians. Aquat. Bot. 1: 269-308

Hughes, T. P., Jackson, J. B. C. (1985). Population dynamics and life histories of foliaceous corals. Ecol. Monogr. 55: 141-166

Hughes, T. P., Keller, B. D., Jackson, J. B. C., Boyle, M. J. (1985). Mass mortality of the echinoid Diadema antillarum Philippi in Jamaica. Bull. mar Sci. 36: 377-384

Jackson, J. B. C. (1977). Competition on marine hard substrata: the adaptive significance of solitary and colonial strategies. Am. Nat. 111: 743-767

Jackson, J. B. C., Buss, L. W. (1975). Allelopathy and spatial competition among coral reef invertebrates. Proc. natl Acad. Sci. USA 72: 5160-5163

Karlson, R. H. (1980). Alternative competitive strategies in a periodically disturbed habitat. Bull. mar. Sci. 30: 894-900

Lessios, H. A., Cubit, J. D., Robertson, D. R., Shulman, M. J., Parker, M. R., Garrity, S. D., Levings, S. C. (1984a). Mass mortality of Diadema antillarum on the Caribbean coast of Panama. Coral Reefs 3: 173-182.

Lessios, H. A., Glynn, P. W., Robertson, D. R. (1983). Mass mortalities of coral reef organisms. Science, N.Y. 222: 715

Lessios, H. A., Robertson, D. R., Cubit, J. D. (1984b). Spread of Diadema mass mortality through the Caribbean. Science 226: $335-337$

Liddell, W. D., Ohlhorst, S. L. (1986). Changes in benthic community composition following the mass mortality of Diadema at Jamaica. J. exp. mar. Biol. Ecol. 95: 271-278

Liddell, W. D., Ohlhorst, S. L., Coates, A. G. (1984). Modern and ancient carbonate environments of Jamaica. Sedimenta 10: 1-98

Miller, R. J. (1985). Succession in sea urchin and seaweed abundance in Nova Scotia, Canada. Mar. Biol. 84 275-286

Moorsel, G. W. N. M. van (1985). Disturbance and growth of juvenile corals (Agaricia humilis and Agaricia agaricites, Scleractinia) in natural habitats on the reef of Curaçao. Mar. Ecol. Prog. Ser. 24: 99-112

Morrison, D. (1984). Mass mortality of Diadema antillarum on a Jamaican coral reef: effect on algal community. Advances in Reef Science, RSMAS, Miami, p. 85-86

Ogden, J. C., Brown, R. A., Salesky, N. (1973). Grazing by the echinoid Diadema antillarum Philippi: formation of halos around West Indian patch reefs. Science 182: 715-717

Ogden, J. C., Lobel, P. S. (1978). The role of herbivorous fishes and urchins in coral reef communities. Environ. Biol. Fish. 3: $49-63$

Pearse, J. S., Hines, A. H. (1979). Expansion of a central California kelp forest following the mass mortality of sea urchins. Mar. Biol. 51: 83-91

Potts, D. C. (1977). Suppression of coral populations by 
filamentous algae within damselfish territories. J. exp. mar. Biol. Ecol. 28: 207-216

Randall, J. E. (1965). Grazing effects on seagrasses by herbivorous fishes in the West Indies. Ecology 46: 255-260

Rosesmyth, M. C. (1984). Growth and survival of sexually produced Acropora recruits: a post-hurricane study at Discovery Bay. Advances in Reef Science, RSMAS, Miami, p. 105-106

Ruyter van Steveninck, E. D. de, Breeman, A. M. (1981). Biomass and relative coverage of benthic algae in the fore reef of Curaçao (Neth. Ant.) in relation to production. Mar. Ecol. Prog. Ser. 6: 257-265

Sammarco, P. W. (1980). Diadema and its relationship to coral spat mortality: grazing, competition and biological disturbance. J. exp. mar. Biol. Ecol. 45: 245-272

Sammarco, P. W. (1982a). Echinoid grazing as a structuring force in coral communities: whole reef manipulations. J. exp. mar. Biol. Ecol. 61: 31-55
Sammarco, P. W. (1982b). Effects of grazing by Diadema antillarum Philippi (Echinodermata: Echinoidea) on algal diversity and community structure. J. exp. mar. Biol. Ecol. 65: 83-106

Sammarco, P. W., Levinton, J. S., Ogden, J. C. (1974). Grazing and control of coral reef community structure by Diadema antillarum Philippi (Echinodermata: Echinoidea): a preliminary study. J. mar. Res. 32: 47-53

Sokal, R. R., Rohlf, F. J. (1981). Biometry, 2nd edn. W. H. Freeman \& Co., San Francisco

Vine, P. J. (1974). Effects of grazing and aggressive behaviour of the fishes Pomacentrus lividus and Acanthures sohal on coral reef ecology. Mar. Biol. 24: 131-136

Wanders, J. B. W. (1977). The role of benthic algae in the shallow reef of Curaçao (Netherlands Antilles) III: The significance of grazing. Aquat. Bot. 3: 357-390

Williams, A. H. (1981). An analysis of competitive interactions in a patchy back-reef environment. Ecology 62: 1107-1120

This article was submitted to the editor; it was accepted for printing on October 3,1986 